\title{
ПОТЕНЦЙНІ МОЖЛИВОСТІ ПОЗААУДИТОРНОЇ РОБОТИ ДЛЯ ІНТЕЛЕКТУАЛЬНОГО РОЗВИТКУ МАЙБУТНІХ УЧИТЕЛІВ ФІЗИКО-МАТЕМАТИЧНОГО ФАКУЛЬТЕТУ ХАРКІВСЬКОГО НАЦІОНАЛЬНОГО ПЕДАГОГІЧНОГО УНІВЕРСИТЕТУ ІМЕНІ Г. С. СКОВОРОДИ
}

\author{
Н. О. Пономарьова \\ д. пед. н., доц., декан фізико-математичного факультету \\ Н. В. Олефіренко \\ д. пед. н., доц., зав. кафедри інформатики
}

О. А. Жерновникова

д. пед. н., доц., зав. кафедри математики

\section{В. В. Масич}

д. пед. н., зав. кафедри фізики

Як зазначається у Концепції розвитку педагогічної освіти, професії педагогічних працівників мають високу суспільну значущість і відповідальність, перебувають під особливою увагою держави. Так, до критеріїв допуску працівників до професійної педагогічної діяльності відносять як наявність у них ступеня вищої освіти за відповідною спеціальністю (програмою підготовки), так і відповідність їхньої професійної кваліфікації системі вимог, які зафіксовано у відповідному професійному стандарті [1].

Аналіз теоретичних наукових досліджень, узагальнення практичного освітнього досвіду свідчать, що високий рівень академічних досягнень не є гарантом успішної кар'єри особистості в подальшій професійній діяльності. Тому в змісті вищої педагогічної освіти, яка розглядається як відправна, все більше уваги надається розвитку загальних (універсальних, ключових) компетентностей і наголошується на необхідності формування у здобувачів вищої освіти вміння безперервно вчитися впродовж життя. У зазначеному аспекті актуальним $\epsilon$ невідкладне оновлення системи організації позааудиторної роботи в закладах вищої освіти (3ВО), яка б надала можливості для професійного і особистісного розвитку та самореалізації учасників освітнього процесу [2].

Позааудиторна робота здобувачів вищої освіти — це особлива форма навчання, за якої майбутній фахівець засвоює необхідні знання, оволодіває уміннями та навичками систематично та планомірно працювати, формує власний стиль професійної діяльності. Зазначимо, що така робота є надзвичайно важливою в процесі фахової підготовки майбутніх педагогів [3]. Домінуючим елементом позааудиторної роботи здобувачів вищої освіти $€$ цілеспрямована й системна самостійна робота.

У наукових працях розкрито різні підходи до розкриття сутності позааудиторної роботи, встановлення іiі різновидів, виокремлено актуальні проблеми організації позааудиторної роботи в ЗВО, перспективи підвищення іiі ефективності (В. Аккерман, А. Алексюк, С. Вітвицька, Л. Григоренко, О. Демченко, М. Донченко, О. Дубасенюк, Л. Кондрашова, А. Кузьмінський, 3. Курлянд, Л. Онучак, І. Соколова, М. Солдатенко).

Зазначені дослідники виокремлюють два типи позааудиторної роботи із здобувачами вищої освіти, як-от: обов'язкова (що являє собою переважно індивідуальну самостійну роботу з метою підготовки до навчальних занять відповідно до навчального плану спеціальності) та додаткова (проводиться понад обов'язковими вимогами навчального плану за керівництвом викладачів, за спеціальним індивідуальним планом чи графіком 3 урахуванням особистих інтересів і нахилів особистості).

Слід відмітити, що обов'язкова позааудиторна робота з майбутніми вчителями досить чітко регламентується усіма компонентами методичної системи навчання навчальної дисципліни (метою, завданнями, змістом навчання, принципами і методами, засобами і формами навчання). Тоді як у сучасних умовах додаткова позааудиторна робота здобувачів закладів вищої освіти вимагає цілеспрямованої організації, яка б грунтувалася на відповідних теоретичних та методологічних дослідженнях, а також враховувала б досвід практиків-освітян.

Традиційним $є$ виокремлення таких основних форм позааудиторної роботи із здобувачами вищої освіти, які широко впроваджуються на фізико-математичному факультеті ХНПУ імені Г. С. Сковороди, а саме:

- індивідуальна — виконання індивідуальних навчально-дослідницьких завдань, рефератів, курсових робіт, магістерських робіт;

- групова - робота в складі постійно діючих наукових студентських товариств, клубів, гуртків, проблемних груп, їх участь у семінарах, тренінгах, майстер-класах;

- масова - участь у відкритих турнірах, конкурсах, конференціях, олімпіадах з навчальних дисциплін за фахом, предметних тижнях. 
Індивідуальна позааудиторна робота — обов'язковий крок до підготовки та залучення здобувачів вищої освіти до самостійної науково-дослідної діяльності, а також до навчально-проектної діяльності.

Слід відмітити, що окрім традиційної роботи з навчальною, довідниковою, науковою, науково-популярною літературою та складанням конспектів, до якої з перших кроків навчання залучаються майбутні вчителі фізико-математичного факультету, в межах усіх навчальних дисциплін активно використовуються завдання, які вимагають роботи із сучасними електронними підручниками та посібниками, освітніми Інтернет-ресурсами, підготовку повідомлень із супроводом презентацій, складання та розв'язування задач, виконання вправ.

На кафедрах фізико-математичного факультету робочими програмами всіх навчальних дисциплін передбачено виконання здобувачами вищої освіти індивідуальних навчально-дослідних завдань або курсових робіт. Викладачі кафедри фізики та кіберфізичних систем, математики, інформатики приділяють особливу увагу особистісному спрямуванню індивідуальної позааудиторної роботи майбутніх учителів, координуючи тематику з їхніми інтересами і для кожного із них зберігаючи провідну спрямованість різних видів позааудиторної роботи. Виконання магістерських досліджень здобувачами освітнього рівня «магістр» на фізико-математичному факультеті орієнтується на вирішення актуальних для сучасної школи проблем, пов'язаних з розробкою науково-методичних питань вдосконалення навчання фізики, математики, інформатики в закладах загальної середньої освіти (33СО). Викладачами усіх кафедр проводяться регулярні консультації, при чому як у очній, так і у дистанційній формах.

Ураховуючи специфіку підготовки майбутніх учителів на кафедрі математики працюють предметний та методичний гуртки, робота в яких вимагає активізацію розумових здібностей майбутніх учителів.

Гурток «Розв' язування олімпіадних задач з математики» (керівник гуртка — к. пед. н., доц. О. Є. Долгова) спрямований на поглиблення й розширення компетентностей майбутніх учителів математики щодо методів розв'язування різних типів олімпіадних задач для школярів. Слід відзначити, що гурток працює на кафедрі математики понад десять років і протягом усього цього періоду здобувачі вищої освіти цілеспрямовано запрошуються представниками З3СО та управлінь освіти м. Харкова та Харківської області до підготовки і проведення математичних олімпіад різних рівнів для школярів.

Гурток «Сучасні підходи до навчання і викладання математики в школі» (керівник гуртка — к. т. н, доц. I. Г. Яловега) зорієнтований на опанування студентами інноваційних підходів до навчання математики. Хоча гурток працює на кафедрі математики тільки з 2018 року, його тематика викликала значну зацікавленість студентської аудиторії. За цей період за результатами роботи гуртківців ними було підготовлено 17 доповідей на різних студентських конференціях, опубліковано 13 тез доповідей.

Гурток «Розв’язування задач шкільних та студентських олімпіад з інформатики» (керівник гуртка д. пед. н., проф. Л. Е. Гризун) є постійнодіючим на кафедрі інформатики. Ознайомлення майбутніх учителів інформатики з найбільш актуальними методами розв'язування олімпіадних задач сприяє їх інтелектуальному розвитку, вихованню творчого підходу до навчання, його активізації, має виключне практичне значення для подальшої професійної педагогічної діяльності. Слід відзначити, що учасники гуртка беруть участь у різних видах олімпіадних змагань з інформатики. Так, наприклад, окрім Всеукраїнської студентської олімпіади з інформатики, здобувачі фізико-математичного факультету у 2019 році брали участь Всеукраїнському етапі олімпіади з інформатики та інформаційних технологій (на базі НАУ «ХАІ» імені М. С. Жуковського), у Всеукраїнській студентській олімпіаді з розробки мобільних додатків у Мелітопольському державному педагогічному університеті імені Б. Хмельницького, 1/8 фіналу щорічної Міжнародної командної студентської олімпіади $з$ програмування АCM-ICPC (The International Collegiate Programming Contest is an algorithmic programming contest) на базі НАУ «XАI» імені М. С. Жуковського), де результатами змагань команда факультету пройшла у чверть фіналу цієї олімпіади.

Через специфічність змісту підготовки майбутніх учителів інформатики до олімпіад саме з програмування та недостатньо високі, на нашу думку, результати участі здобувачів вищої освіти у зазначеному виді олімпіадних змагань, з метою оновлення та диверсифікації олімпіадної підготовки з вересня 2019 р. на кафедрі інформатики започатковано роботу спеціалізованого гуртка «Розв’язання олімпіадних завдань з програмування» (керівник гуртка - д. пед. н., професор О. Г. Колгатін). До участі у роботі гуртка запрошено майбутніх учителів різних курсів, передбачено залучення до проведення занять як найдосвічених викладачів кафедри, так і професійних програмістів, фахівців із різних сегментів IT-індустрії.

Особливо відзначимо, з огляду на специфіку IT-сфери та з точки зору створення кращих можливостей для здобувачів вищої педагогічної освіти щодо ознайомлення зі світовим досвідом інформатичної науки, їхньої самостійної участі у зарубіжних конференціях, проектах, міжнародних олімпіадах, учасники освітнього процесу потребують удосконалення підготовки з англійської мови за професійним спрямуванням. На кафедрі інформатики з 2012 року працює постійно діючий англомовний дискусійний клуб «Science around us», тематика якого передбачає вивчення та обговорення новітніх зарубіжних та вітчизняних досягнень в галузі IKT, а робота клубу зорієнтована на активну участь майбутніх учителів у підготовці і проведенні засідань. У робо- 
ті клубу передбачено застосування нетрадиційних інтерактивних методик для сприяння оволодіння розмовним англійським мовленням у межах заявленої тематики.

Щодо кафедри фізики та кіберфізичних систем, то понад 15 років тут працює гурток-семінар «Історія фізико-математичних наук та впровадження комп'ютерних технологій в лабораторний фізичний експеримент» (наукові керівники - к. фіз.-мат. н., доц., проф. кафедри фізики та кіберфізичних систем С. Б. Малець, к. фіз.-мат. н., доц., проф. кафедри фізики та кіберфізичних систем В. М. Сергєєв). Предметом навчання у гуртку є вивчення історії розвитку фізичних наук та дослідження ролі фізичного експерименту в становленні фізики.

Гурток «Астрофізика та історія розвитку астронавтики» (науковий керівник - к. т. н., доц. М. Г. Александров) зорієнтований на формування сучасних поглядів майбутніх учителів фізики на сферу використання космічного простору, їх поглиблене ознайомлення з природою космічних тіл, їх будовою.

До участі у роботі гуртків залучаються здобувачі освітнього рівня «бакалавр» першого курсу. Тому слід зважити, що діяльність зазначених гуртків, $є$ важливою для майбутніх учителів, ураховуючи як суттєво різний рівень початкової фізико-математичної підготовки, так і об'єктивні і суб'єктивні труднощі в навчанні фізичних дисциплін, подоланню яких ефективно допомагає гурткова робота.

Успішній адаптації туркменських здобувачів вищої освіти, які останні 10 років складають відчутну частку контингенту на фізико-математичному факультету, сприяють групові консультації, які систематично проводить викладач кафедри фізики та кіберфізичних систем О. В. Юрченко.

Результати роботи гуртків по кафедрі фізики та кіберфізичних систем протягом 2019 року були представлені на студентських наукових конференціях як в університеті, так і у інших навчальних закладах освіти (наприклад, у Харківському радіотехнічному коледжі, Харківському планетарії імені Ю. О. Гагаріна тощо). Напрацювання гуртківців демонструвалися відвідувачам днів відкритих дверей фізико-математичного факультету, учасникам «Днів науки» та інших масових заходів.

У 2019 році завдяки перемозі здобувачів вищої освіти кафедри фізики та кіберфізичних систем у міському конкурсі студентських проектів «Харків — місто молодіжних ініціатив» (проект «Відкрита фізика. Фізичні іграшки», автор - здобувач 4 курсу фізико-математичного факультету групи 4Ф Равх Іванна, науковий керівник - зав. лабораторією кафедри фізики П. Л. Токарев) та отриманні грошової винагороди на реалізацію мети проекту на кафедру було закуплено таке обладнання:

- котушка Тесла;

- набір демонстрацій з механіки та електрики;

- набір «Магнітна левітація»;

- 3Д ручки 2го та 5-го покоління, пластик до ручок;

- антигравітаційна машинка (2 шт.);

- квадрокоптер з камерою;

- набір для творчості «Літак на сонячній батареї»;

- набір для творчості «Поїзд на магнітній подушці»;

- набір для творчості «Торнадо»;

- набір для творчості «Голографічний проектор»;

- набір для творчості «Вантажівка на енергії солі»;

- набір для творчості «Катер на повітряній подушці»;

- набір для творчості «Екоракета».

У вересні-жовтні 2019 року за усіляким сприянням та підтримкою керівництва ХНПУ імені Г. С. Сковороди, за кошти МОН України для кафедри фізики та кіберфізичних систем фізико-математичного факультету вперше за тривалий термін було закуплене сучасне обладнання, серед якого:

- модель двигуна внутрішнього згорання;

- набір лабораторний «МолеНабір лабораторний «Молекулярна фізика та термодинаміка»» ;

- набір «Альтернативна енергія - перетворення»;

- набір «Механіка: кінематика, динаміка»;

- тесламетр - прилад для вимірювання індукції магнітного поля;

- комплект для класу робототехніки - LEGOROBOCLASS (6 наборів).

Наявність такого обладнання дозволяє говорити про відкриття якісно нових напрямів усіх видів позааудиторної роботи кафедри фізики та кіберфізичних систем, так і взагалі про перспективи сучасного оновлення та прогресивного розвитку фізичних предметних та методичних досліджень.

Масові організаційно-виховні заходи на фізико-математичному факультеті є важливою складовою позааудиторної роботи.

32010 року для здобувачів вищої освіти усіх спеціальностей фізико-математичного факультету кафедрою інформатики проводиться щорічний конкурс авторських програмних розробок з метою виявлення та під- 
тримка творчих здібностей молоді в галузі IКТ. До участі у конкурсі запрошуються здобувачі вищої освіти фізико-математичного факультету та інших факультетів, здобувачі З3СО. Конкурс передбачає демонстрацію учасниками авторських програмних розробок, виконаних у відповідності до оголошених умов та теми у встановлені терміни. Під час проведення конкурсу всі учасники забезпечуються плановими консультаціями провідних фахівців кафедри з питань розробки програмних продуктів. До складу журі конкурсу входять викладачі та співробітники кафедри інформатики, актив секції інформатики студентського наукового товариства. На етапі попереднього розгляду журі конкурсу у складі робочих груп виконує рецензування робіт та надає авторам рекомендації щодо поліпшення якості програмних продуктів, які вони можуть урахувати для подальшої участі в конкурсі. Під час проведення відкритого підсумкового туру журі конкурсу визначає три кращі розробки, автори яких отримують заохочення. Матеріали конкурсів зберігаються у фонді кафедри та надаються для вільного користування. Наведемо приклади тематики конкурсних робіт: «Інформатика мій вибір», «Слобожанщина - квітка України», «Урок моєї мрії», «Він був кріпаком і став велетнем у царстві людської культури. До ювілею Т. Г. Шевченка», «Живи, Україно, живи для краси, для сили, для правди, для волі!», «3 англійською - у світ глобальний!», «Світ ІТ-професій», «Комп’ютер зсередини», «Книга це країна і час: 3 минулого в майбутнє». За період роботи учасниками було підготовлено більше ніж 55 робіт.

Здобувачі вищої освіти фізико-математичного факультету й самі систематично залучаються до підготовки та проведення низки позааудиторних проектів, що передбачають проведення масової роботи із здобувачами З3СО міста Харкова та Харківської області: шкільних предметних тижнів, студентських та учнівських конференцій та читань, районних та міських олімпіад та турнірів для школярів, майстер-класів та тренінгів для учнів та вчителів, виїзних профорієнтаційних зустрічей та індивідуальних й групових консультації з учнями та вчителями Харківського регіону. Така робота безсумнівно сприяє вдосконаленню особистості майбутнього учителя, яка самостійно формує власний досвід, прагне активно реалізувати свої можливості, здатна до усвідомленого та обгрунтованого вибору рішень у різних професійних ситуаціях. Найяскравішими масовими заходами 2019 року були дні відкритих дверей, День науки, Ніч науки та Наукові пікніки.

Найочікуванішим масовим заходом року на фізико-математичному факультеті є науково-предметний тиждень «Інтеграція наук у цифровому просторі» 3 метою активізації інтересу майбутніх учителів до набуття знань 3 найважливіших наук цифрової ери - інформатики, математики та фізики. Упродовж тижня відбуваються різнопланові конкурси, масові заходи, інтелектуальні змагання, студентські конференції $з$ актуальних питань інформатики, круглі столи, де обговорюються новації в інформаційних технологіях.

Особливу зацікавленість протягом останніх років викликали насичені та змістовні предметні брейн-ринги та брейнстормінги, майстер-класи з інтерактивної фізики, медіаосвіти, робототехніки, 3D моделювання та 3D друку тощо, квести та онлайн веб-квести та багато інших заходів.

Важливо, що концепція тижня, яка передбачає органічне поєднання заходів наукового спрямування з розважально-пізнавальною програмою прояв творчої активності й ініціативності учасників освітнього процесу, робить дійсно масовим заходом, у якому приймають участь здобувачі вищої освіти всіх курсів фізико-математичного факультету — від першого до випускного - i викладацькі колективи всіх кафедр факультету.

Отже, проведений аналіз та узагальнення досвіду роботи кафедр фізико-математичного факультету ХНПУ імені Г. С. Сковороди із організації позааудиторної роботи з майбутніми учителями фізики, математики, інформатики свідчить, що позааудиторна робота має низку суттєвих переваг, серед яких: відсутність часових обмежень, виключення авторитарного керівництв з боку професорсько-викладацького складу, можливість якнайповнішого врахування інтересів суб'єктів освітнього процесу, позитивний влив на психологічний клімат у освітньому середовищі, активне сприяння самореалізації особистості. Особливо значущим є те, що позааудиторна робота сприяє інтелектуальному розвиткові особистості, самостійності, креативності, конкурентоздатності майбутнього вчителя.

\section{Література}

1. Концепція розвитку педагогічної освіти. URL: https://mon.gov.ua/ua/news/mon-proponuye-do-gromadskogoobgovorennya-proekt-koncepciyi-rozvitku-pedagogichnoyi-osviti (дата звернення 19.10.2019).

2. Пономарьова Н. О. Концептуальні засади постановки науково-дослідної роботи студентів вищих педагогічних навчальних закладів : матеріали Міжнар. теор.-методолог. конф. «Методологічні питання наукового дослідження в педагогіці та соціальній педагогіці» (Харків, 27.02.2007). Харків : ХГОКЗ, 2007. С. 50-51.

3. Смерчак Л. Позааудиторна самостійна робота у системі професійної підготовки майбутніх соціальних педагогів // Молодь і ринок. 2011. №12 (83). С. 63-65. 